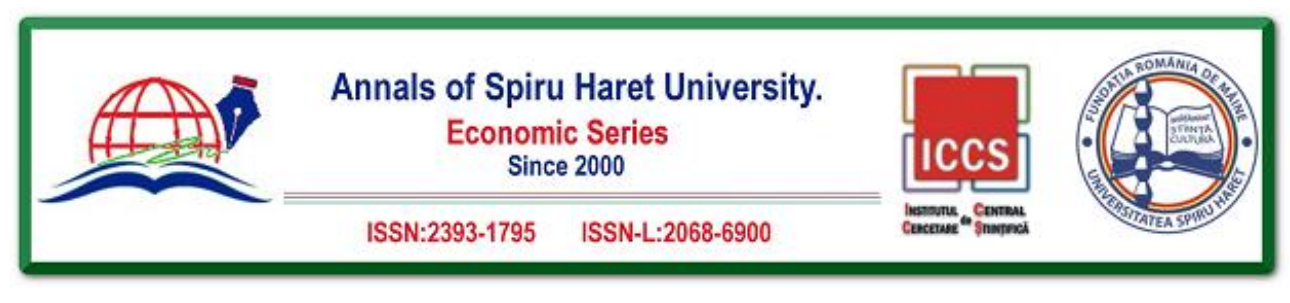

Issue $4 / 2018$

\title{
NIGERIA'S REVENUE ALLOCATION AND SUSTAINABLE ECONOMIC DEVELOPMENT
}

\author{
Cordelia Onyinyechi OMODERO ${ }^{1}$, Joseph Uche Belonwu AZUBIKE ${ }^{2}$, \\ Michael Chidiebere EKWE ${ }^{3}$ \\ ${ }^{1,283}$ Department of Accounting, College of Management Sciences, \\ Michael Okpara University of Agriculture, Umudike, Abia State, Nigeria, \\ E-mail: cordeliaomodero@yahoo.com
}

How to cite: OMODERO, O. C., AZUBIKE, J. U. B., \& EKWE, M. C. (2018). "Nigeria’s Revenue Allocation and Sustainable Economic Development." Annals of Spiru Haret University. Economic Series, 18(4), 97-112, doi: https://doi.org/10.26458/1846

\begin{abstract}
Sustainability of economic development in Nigeria has been a serious challenge despite the huge revenue allocated to the three tiers of the government on a monthly basis from the federation account. This recurring decimal has left the country in a pitiable condition with inadequate infrastructures to carry on the economic activities. The study examines the extent to which revenue allocation enhances economic development using time series data obtained from CBN Statistical Bulletin, which covered a period from 1981 to 2016. Ordinary Least Squares technique was employed and the findings revealed that FASG and NDSD have significant negative impact on PCI while FAFG has insignificant negative impact on PCI. On the contrast, the result shows that FALG has a robust significant positive impact on PCI. The study attributes this poor performance to misuse of resources and suggests that more stringent measures be employed by the government to fight graft in the public sector and among government officials. This will help to curb corrupt practices and ensure efficient and effective use of resources to boost economic development.
\end{abstract}

Keywords: revenue allocation; economic development; federation account; resources; Nigeria.

JEL Classification: Q01 


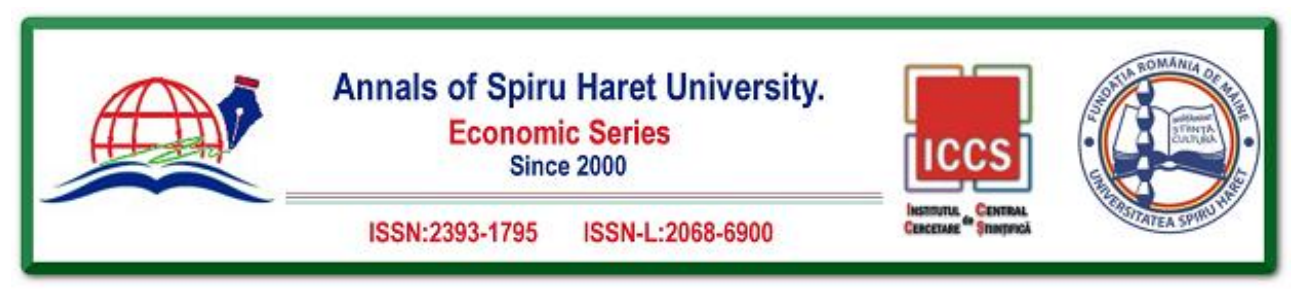

\section{Issue 4/2018}

\section{Introduction}

Revenue allocation has been referred to as the criteria, process and method of sharing a federation's financial resources among the various tiers of government in the federation in such a peaceful way that guarantees development, progress and enhances unity [NRMAFC, 1992]. Onu (1994) defined revenue allocation as the mechanism for the sharing of the country's financial resources among the different tiers of government in the federation, with the overall objective of enhancing economic growth and development, minimizing inter-governmental friction and promoting national unity. According to Ikeji (2011), revenue allocation has been described as a method(s) of sharing the centrally generated revenue among the different tiers of government and how the amount allocated to a particular tier is shared among its components. From the various definitions, it is pertinent to establish that revenue allocation is the distribution of a country's revenue among the various levels of government in such a manner that guarantees economic development. The definitions of NRMAFC (1992) and Onu (1994) have better described the focus of this study, which seeks to evaluate the impact of federation account allocation and internally generated revenue on economic development in Nigeria.

It is important to note that revenue allocation to the three tiers of the government is major for the economic development, which is also known as fiscal federalism [Ekpo, 2004]. Economic growth theories maintain that revenue allocation is meant to enhance economic development [Domar, 1946; Harrod, 1939; Romar, 1994; Solow, 1956; Swan, 1956]. Therefore, the revenue allocated to the Nigerian federating units is to carry out their various constitutional expenditure responsibilities that enhance economic development in the country [Dagwom, 2013]. However, this major aim of revenue allocation has not been achieved over the years. For several decades now, sustainable economic development has eluded the country due to mismanagement of revenue intended to be used to develop the country. The revenues allocated to the three tiers of the government for all these years have ended up in private pockets, thereby leaving the country underdeveloped. From 1981 to 2016 the study examined, revenue allocations to the federal government, state government, local government and Niger Delta States Derivation have been accounted to be N72,120.01B, N20,270.72B, N10,357.03B, N12,415.84B respectively (CBN Statistical Bulletin, 2016). These figures are not commensurate with the poor level of economic development witnessed in the country. The ugly situation has led to arms carrying and destruction of oil pipelines by the youths in the Niger Delta region of the country. There is lack of infrastructures and roads to boost business activities in all 


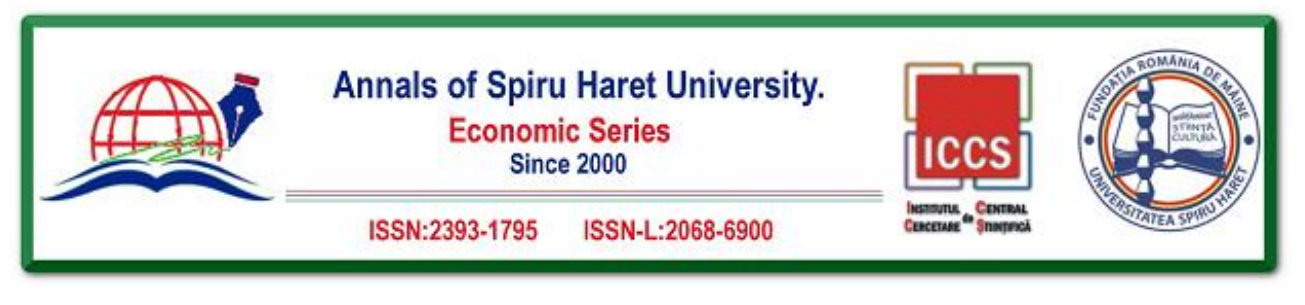

Issue $4 / 2018$

parts of the country, yet so much money is allocated to the three tiers of the government on a monthly basis both for recurrent and capital expenditure.

\section{Objective of the Study}

The major objective of this study is to determine the impact of revenue allocation on economic development in Nigeria. The study specifically seeks to:

1. Examine the impact of revenue allocation to federal government (FAFG) on per capita income (PCI).

2. Investigate the influence of revenue allocation to state government (FASG) on per capita income (PCI).

3. Evaluate the effect of revenue allocation to local government councils (FALG) on per capita income (PCI).

4. Establish the impact of Niger Delta States Derivation (NDSD) allowance on PCI.

\section{Study Hypotheses}

To pursue the above study objectives, the following null hypotheses were formulated:

$\mathrm{Ho}_{1}$ : FAFG does not have significant impact on PCI.

$\mathrm{Ho}_{2}$ : FASG does not significantly influence PCI.

$\mathrm{Ho}_{3}$ : FALG does not affect PCI significantly.

$\mathrm{Ho}_{4}$ : NDSD does not have significant impact on PCI.

\section{Literature review}

\section{Conceptual Review}

Revenue Allocation in Nigeria

Revenues that flow into the federation account can be classified into oil and nonoil revenue. Under the oil revenue, we have: oil pipeline license fees; royalty on extraction of oil; rent of oil well and grounds; sale of petroleum and gas; penalty for gas flaring. The non-oil revenue includes: personal income tax; companies income tax; capital gains tax; withholding tax and all four forms of indirect taxes [ATSWA, 2009]. The statutory revenue allocation formula is the recognized and acceptable yardstick by which all revenue accruing to the federation account is to be distributed among the federal, state and local government councils and any other beneficiary as may be specified by law. This varies from time to time based on the terms and procedures as may be prescribed by law [ATSWA, 2009]. There are two major types 


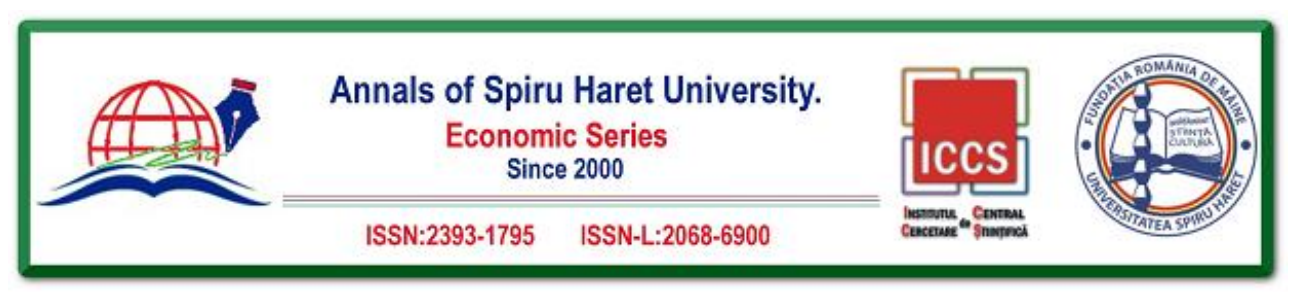

\section{Issue 4/2018}

of revenue allocation formulas in Nigeria. The two are basic, the vertical allocation and horizontal allocation [Micaiah, 2015].

Vertical allocation formula (VAF). Vertical allocation refers to the sharing of the federation's revenue among the three tiers of government that make up the federation. Through vertical allocation method, the allocation that goes to the federal, state and local government is determined. VAF shows the percentage allocation to the three tiers of government. This formula is applied vertically to the total volume of disbursable revenue in the Federation account at a particular point in time.

Horizontal allocation formula (HAF). Horizontal allocation provides a platform for sharing revenue among states and how the states distribute the revenue among the various local governments, communities and towns within the states. The formula is applicable to states and local governments only [Micaiah, 2015]. According to Bashir (2008), it is possible to conclude that horizontal allocation formula is for intra-tier sharing amongst the 36 states and the 774 local governments in Nigeria.

\section{Revenue Allocation Principles}

At this juncture, it is expedient to review the underlying principles of revenue allocation in Nigeria. Although, Nnamocha (2002) has asked: at what stage in the revenue allocation system is a principle used or asked for and why? These are questions and issues begging for an answer. However, the following principles have been identified by [Nnamocha, 2002; Ihe \& Umeaka, 2006]:

1. Tax effort. By giving more allocations to states that make more effort to collect taxes due to them, this principle is thus used to motivate states to exploit their tax potential and capacities.

2. Population. This principle allows allocation of more resources to states/LGAs that are heavily populated than others. The argument here is that states with high population will also be enriched with human and natural resources and so deserves less allocation [Odigwe \& Aibieyi, 2015].

3. Even development. To ensure even development and uniform progress, poorer states are given more revenue. This helps to spread economic growth and development. The principle also helps to reduce inequalities and imbalances.

4. Derivation. This principle states that regions/states that produce higher revenue to the federal government should receive a commensurate allocation. That is, the allocation of resources to them should be higher too. It was first recommended by 


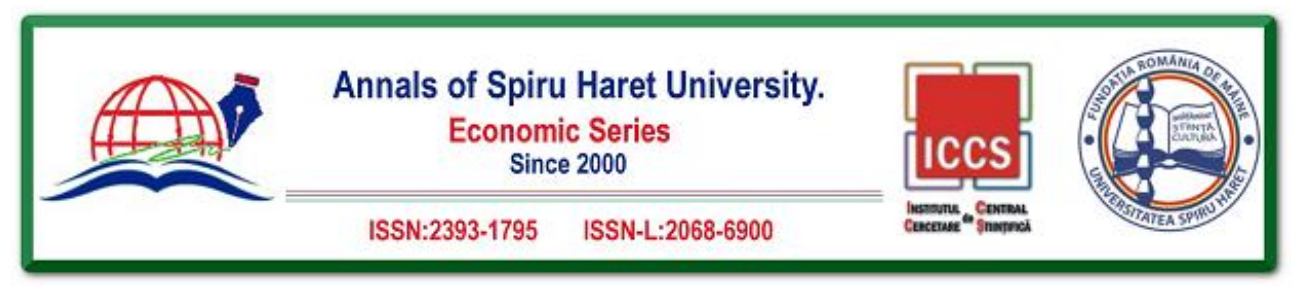

Issue $4 / 2018$

the various revenue allocation commissions set up in the past. Orluwene (2008) has also suggested that revenue sharing should be principally based on derivation. This basis will prompt all states to go back to their roots. That is, agricultural and cash crops growing for export. Then the dependence on oil revenue will be curtailed.

5. National interest. Allocation should be based on things that are of high social importance such as education and security which unite the country.

6. Equality of states. The principle advocates sharing of revenue equally among states despite the economic endowments in each state of the federation. This is because each state is expected and required to carry out certain level of responsibilities.

7. Principle of need. The level of need of every state should determine the revenue allocation to the state. This is supported by the recommendation of HicksPhillipson Commission (1951) and Raisman Commission (1957). For instance, some newly created states require more funds than the existing ones. This has been argued by Odigwe and Aibieyi (2015). Their reason is that no particular state has the most crucial need and so the principle of need is not beneficial if it is not based on population census.

8. Equality of access to development opportunities. This principle believes that allocation of revenue should be more in favour of those that are below certain level of development. This will enable them have to equal access to development and growth.

9. Independent revenue effort. This principle stresses on more allocation to states that are able to collect revenues due to them.

10. Continuity of government action. Subsequent revenue allocation is not expected to fall below the previous allocation. This is why revenue should be shared in such a manner that the central government will not have the problem of given less than the previous allocation.

11. Absorptive capacity. Revenue allocation is based on the ability of the states to make proper use of the revenue allocated to them. States that are economically advanced will not find it difficult to properly absorb any increase in revenue without wastages or fraud.

12. Land Area. The proportion of land occupied by the states also determines the revenue allocation. This principle does not make any economic impact especially in those areas that have Sahara deserts, where nobody lives. Most states like Lagos and Rivers State are heavily populated and should not be assessed by this principle, but rather the population due to migration of people from the rural area to the urban cities in search of jobs. 


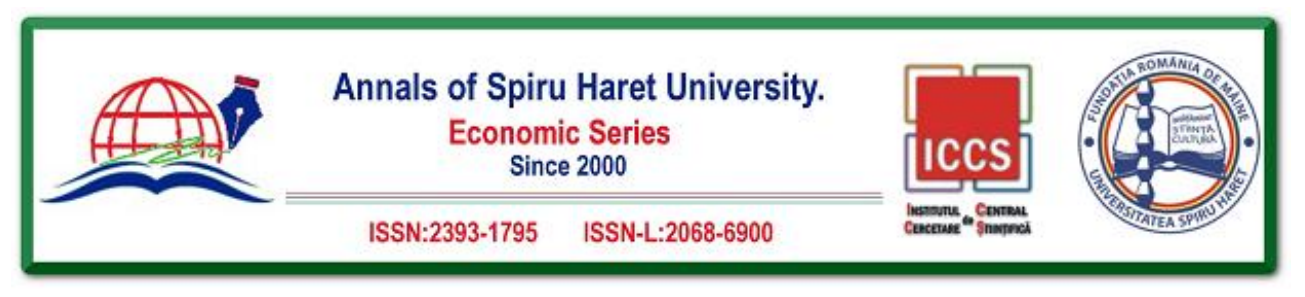

\section{Issue 4/2018}

13. Principle of school enrolment. The principle suggests that the number of pupils in school in the state/LGA should be considered in resource allocation. This principle also has some issues, although education is a vital part of economic development. However, there are places where people refuse to be enrolled in schools, but prefer commercial trading, animal rearing and other forms of craft. In that case, school enrolment basis will not be fair to them.

14. Pupil of school age not in school. This principle stipulates that higher allocation should be given to the states with more pupils of school age that are not in school so as to enable such state/LGA to send them to school.

15. National minimum standard. Revenue allocation should be done with the primary aim of maintaining national minimum standard in all the states in the federation of Nigeria. This principle is in line with the recommendation of Dina Commission (1969). States that do not have certain levels of education and perhaps health services are to be allocated more revenue to meet up with the national minimum standard.

\section{Revenue Allocation Commissions/Committees in Nigeria}

There are recommendations and efforts from various revenue allocation commissions/committees established in Nigeria in the past and present to harmonize allocation issues, yet the fight for resource control is still not resolved.

1. Phillipson Commission (1946). This commission recommended the use of derivation and even development as criteria for the distribution of revenue. By derivation, the commission means each unit of government would receive from the central budget the same portion it has.

2. Hicks-Phillipson Commission (1951). This commission recommended need, derivation, independent revenue or fiscal autonomy and national interests as the criteria for revenue sharing.

3. Chicks commission (1953). The commission recommended derivation.

4. Raisman Commission (1957). It recommended need, balanced development and minimum responsibility. Percentage division of $40 \%$ to the north, $31 \%$ to the east, $24 \%$ to the west and $5 \%$ to Southern Cameroon.

5. The Binns Commission (1964). This commission rejected the principles of need and derivation. In their place, it proposed regional financial comparability and percentage division of $42 \%$ to the north, $30 \%$ to the east, $20 \%$ to the west and $80 \%$ to the mid-west.

6. Dina Commission (1969). It recommended national minimum standards, balanced development in the allocation of the state's joint account and basic need. 


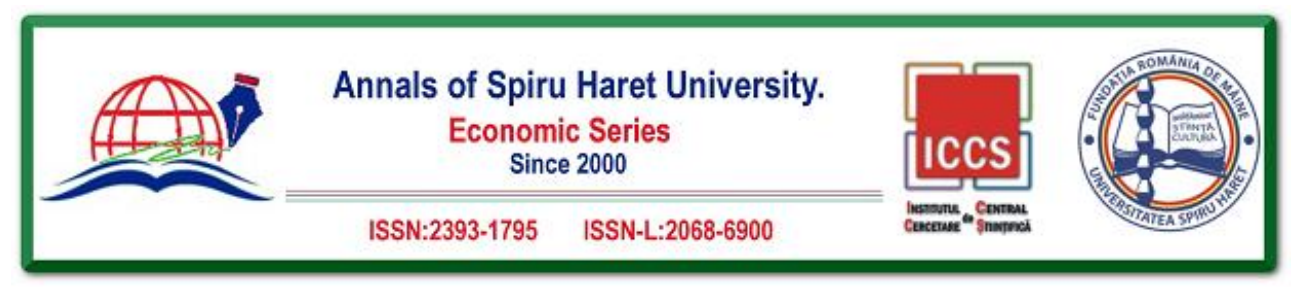

Issue 4/2018

7. Aboyade Technical Committee (1977). The committee recommended revenue sharing among the three tiers of government in the following order: Federal (53\%), States (30\%), Local Governments (10\%) and Special Fund (7\%). The committee also recommended the sharing among states to be based on the following principles: national minimum standard for national integration (22\%), equality of access to development opportunities (25\%), absorption capacity (20\%), fiscal efficiency (15\%) and independent revenue effort (18\%).

8. Okigbo Committee (1980). This committee suggested that the revenue sharing percentages for the three tiers of government should be as follows: Federal (53\%), States (30\%), Local Governments (10\%) and Special Fund (7\%). Percentages to the state are based on the following principles: population (4\%), equality (4\%), social development (15\%) and internal revenue effort (5\%).

9. Danjuma Commission (1988). The commission recommended percentages be as follows: Federal (50\%), States (30\%), Local Government (15\%) and (5\%) for Special Fund.

10. RMAFC (1989). The establishment of Revenue Mobilization Allocation and Fiscal Commission was the way the federal government tried to resolve all revenue allocation issues. RMAFC is empowered by the Constitution to disburse revenue from the federation account, review the allocation formula as need arises, act on advisory capacity to the federal, state and local governments on how to generate and efficiently utilize revenue, determine suitable remuneration for political office holders and also perform other functions that may be required by law from the commission [Arowolo, 2011].

\section{Per Capita Income}

Olaoye and Adedeji (2017) described per capita income as the amount of money earned per person in a country. It measures the standard of living and quality of life of an individual person in a country. Per capita income is the total national income (GDP) divided by the number of people in the nation [Farlex, 2018]. It measures the income earned per person in a given area (city, region, county, etc.) in a specified year. It is calculated for a country by dividing the country's total national income (GDP) by its total population. It includes children and non-working population which serves as an indicator of a country's living standards (Business Dictionary, 2017). According to World Bank (2017) Per Capita, GDP is gross domestic product divided by midyear population (that is population as of 1 July for the same year). It means GDP per person. It is an important indicator of economic performance and shows the 


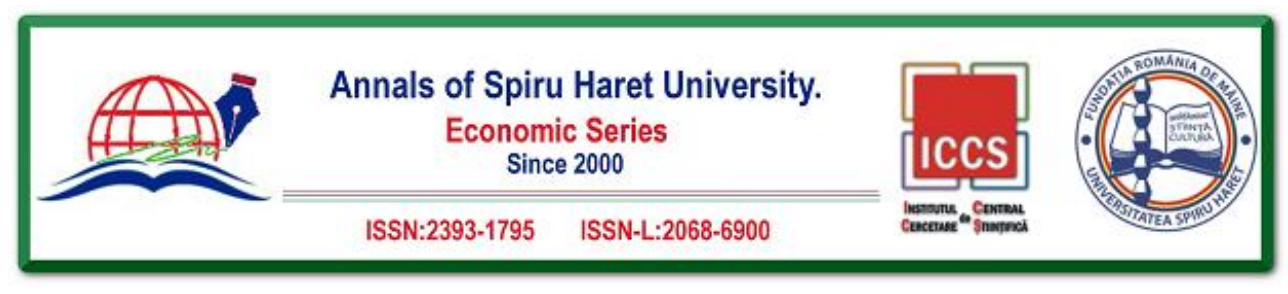

\section{Issue 4/2018}

average living standard and economic wellbeing of a country [Focus Economics, 2017]. A rise in per capita GDP signals growth in the economy and tends to reflect an increase in productivity. A higher per capita GDP is equal to a higher standard of living [Investopedia, 2017]. Gross National Income (GNI) per capita is a GNI divided by midyear population. GNI is the sum of value added by all resident producers plus any product taxes (less subsidies) not included in the valuation of output plus net receipts of primary income (compensation of employees and property income) from abroad [World Bank, 2017]. Therefore, it is believed that economic growth of a nation should be truly reflected in the increase in per capita income of individual persons in the country [Olaoye and Adedeji, 2017].

\section{Theoretical Review}

This study reveals an endogenous economic growth theory studied by - the author - Roma (1994). The theory advocates all government policies that encourage economic development and growth which include revenue allocation to the various levels of the government. In Nigeria, revenue allocation is in the way and manner in which fiscal decentralization is practiced to boost economic growth and development across the 36 states of the federation including the Federal Capital Territory, Abuja.

The revenue distribution is usually aimed at making resources available to the different levels of the government to pursue expenditure responsibilities within their jurisdiction which will result to a collective and sustainable economic development within the country as a whole.

\section{Empirical review}

Faridi (2011) carried out a study on the contribution of fiscal decentralization to economic growth in Pakistan. The study covered the period of 1972 to 2009 and the ordinary least squares estimation was employed for the analysis. At the time of the study, other factors to measure economic growth in Pakistan were not substantial except fiscal decentralization indicators of revenue and expenditure functions. The dependent variable was the Gross Domestic Product while the independent variables used were the revenues and expenditures of the government. All variables were expressed in million rupees. The data sources include Pakistan Economic Survey (various issues), hand book of statistics on Pakistan economy (2005) and fifty years of Pakistan Statistics. The result of the study indicated that both revenue and expenditures of government as measure of fiscal decentralization had positive association with the economic growth. The paper also found a positive and 


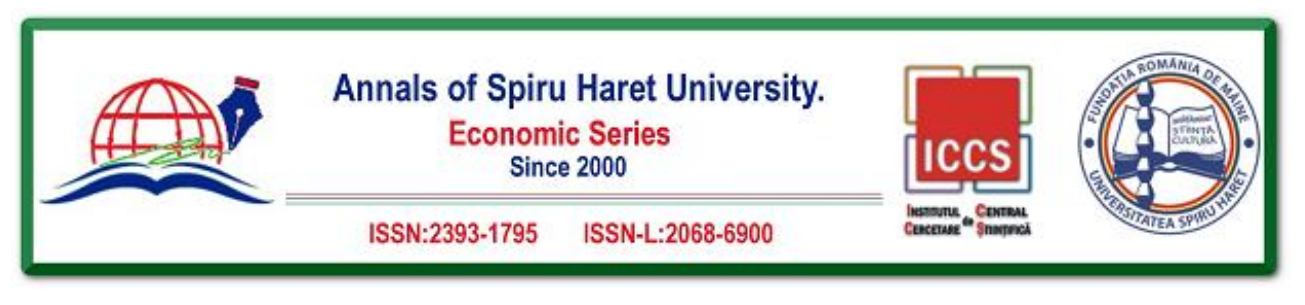

Issue 4/2018

significant impact of fiscal decentralization on economic growth. Based on the empirical result, the study suggested that provincial and local level governments should be given more autonomy and authority in fiscal matters in Pakistan.

Usman (2011) researched on revenue allocation formula and its impact on economic growth process in Nigeria. He focused on the effect of revenue allocation formula adopted on economic growth and development in Nigeria for the period spanning from 1960-2010. The dependent variable used is the real gross domestic population growth rate while the independent variables are the growth rate of share of federal, state, local governments and inflation rate. The statistical tools employed were ordinary least squares method and correlation coefficient to estimate its properties and measure the goodness of fit of the regression line. However, the result showed that the share of local and federal governments from the federation account contributed to the economic growth process in Nigeria, while the share of state governments from the federation account did not perform as expected.

Dagwom (2013) investigated revenue allocation and economic development in Nigeria: an empirical study. The study specifically examined the impact of revenue allocation to the three tiers of government on the real gross domestic product in Nigeria using time series data covering the period of 1993 to 2012. The dependent variable used for the study was the Real GDP, while the independent variables include revenue allocation from the federation account to the Federal Government, State Government and Local Government Councils. Stationarity test of the variables was conducted using Augmented Dickey Fuller unit root test while Johansen Cointegration test was used to test long run relationship. The regression result revealed that revenue allocation to the federal government has a $0.06 \%$ impact on economic growth while the revenue allocation to the local governments increases economic growth by $0.34 \%$ which is far higher than that of the federal government. The result of the revenue allocation to the state government showed negative effect of $-0.13 \%$ on economic growth.

Ojide and Ogbodo (2015) carried out a study on the federation account allocation in Nigeria: implication for growth. The paper considered whether there is statistical growth evidence of federal government's allocation share (FGAS), state governments' allocation share (SGAS) and state governments' internally generated revenue in Nigeria. The time series data employed covered the period of 1970 2009. Distributed lag model was used to analyze the relationship between allocations (federal and state governments) and economic growth. The gross domestic product is expressed as a function of the revenue allocation to federal, state and state internally 


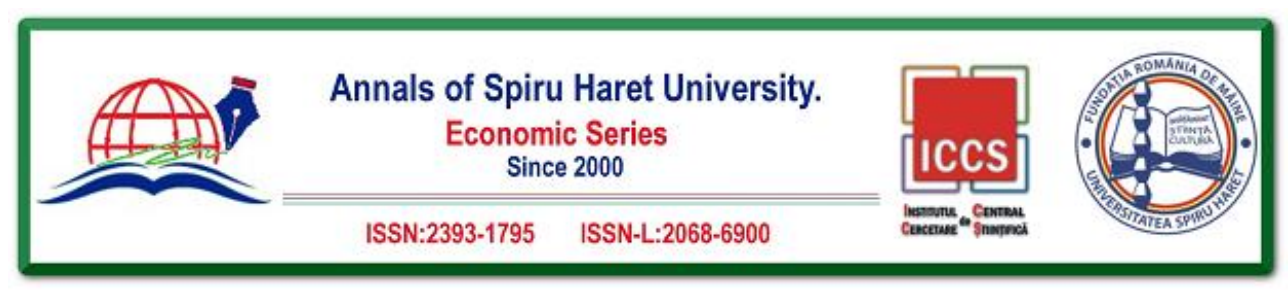

\section{Issue 4/2018}

generated revenue. The regression result showed that the federal government allocation share and the state governments' internally generated revenue $(0.55 \%$ and $0.17 \%$ respectively) have positive and significant association with the economic growth, while the state governments' allocation share has a negative and significant relationship with the growth $(-0.64 \%)$. The result of this study suggests that state governments' allocation share has a negative impact on the economic growth.

Ohiomu and Oluyemi (2017) researched the fiscal federalism and economic growth nexus: empirical evidence from Nigeria. The study made use of Cointegration diagnostics tests and Error Correction Model (ECM) on E-Views 8. Time series data used were gathered from CBN statistical bulletin and spanned from 1984 - 2015. The dependent variable identified in this study was the Real Gross Domestic Product, while the revenue allocation to the federal, state and local governments served as the explanatory variables. The result of the study revealed that revenue allocation to state government increases economic growth by $0.26 \%$ which shows a positive effect on economic growth. In other words revenue allocation to state governments contributed to economic growth in Nigeria. Revenue allocation to federal government showed a minute increase of $0.001 \%$ to the economic growth despite the share given to it for national projects and general economic development. The result on the allocation to the local government revealed a negative effect of $0.03 \%$. The study suggested a review of the current revenue sharing formula which should be centered on responsibilities of each tier of the government.

\section{Gap in Literature}

The current study covered a period from 1981 to 2016 and included, among the independent variables, the derivation allowance which is given to Niger Delta States as a way of complying with the derivation principle and compensating the states as contained in section 162(2) of the 1999 Constitution of the Federal Republic of Nigerian. The study adopted per capita income (PCI) as an economic indicator to measure sustainable economic development as against the usual real gross domestic product (RGDP) used by other scholars mentioned above.

\section{Methodology}

The study made use of ex-post facto and descriptive research designs. The reasons underlying the adoption of these two research designs are that the research data are all historical in nature which implies that they were already in existence as at the time of this study (ex-post facto). The descriptive research design availed the 


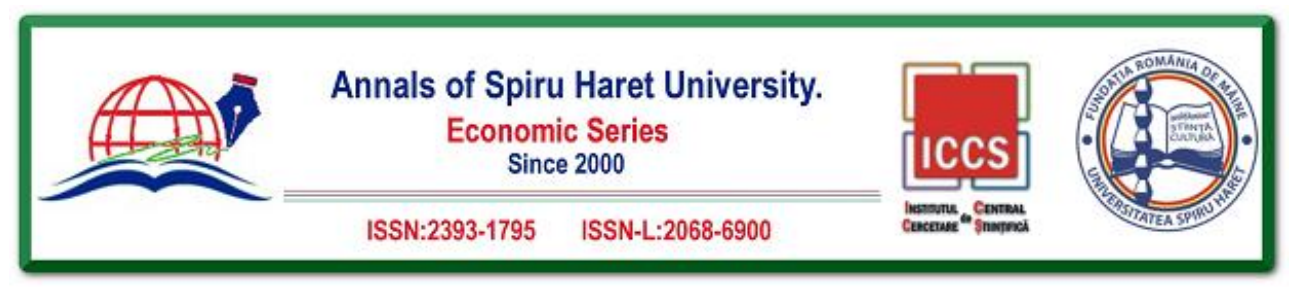

Issue 4/2018

opportunity to numerically collect the data and statistically analyzed them to arrive at the results which serve as empirical evidences in this field of study. All data on PCI (dependent variable), FAFG, FASG and FALG (independent variables) were gathered from the CBN Statistical Bulletin, 2016 edition. The study made use of Augmented Dickey Fuller Unit root testing to establish stationarity of data to avoid spurious regression result. Ordinary Least Squares (OLS) method was used to perform the multi-regression analysis with the aid of e-views version 9.

The model adopted for the study is specified below:

$$
\mathrm{Y}_{3}=\alpha+\beta 1 X 1+\beta 2 \times 2+\beta 3 \times 3+\beta 4 X 4+\mu \mathrm{i}
$$

Where:

$$
\mathrm{Y}_{3}=\text { PCI }
$$

$\mathrm{X}=$ determinant of economic development

$\mathrm{X} 1=$ FAFG

$\mathrm{X} 2=$ FASG

$\mathrm{X} 3=$ FALG

$\mathrm{X} 4=\mathrm{NDSD}$

$\beta=$ determines the relationship between the independent variable $\mathrm{X}$ and the dependent or gradient/slope of the regression measuring $\mu \mathrm{i}=$ normally distributed error term.

\section{Data Analysis and Interpretation of Results}

Dependent Variable: $\quad$ Per Capita Income (PCI).

Independent Variables: FAFG, FASG, FALG and NDSD.

The descriptive statistics of the model on table 1 shows that the standard deviation of the distribution in PCI and FAFG is a lower spread and are below the mean, while the rest of the variables have a wider spread which is above the mean. The implication is that, the higher the dispersion or variability, the greater the magnitude of the deviation from the mean value. Standard deviation is only a mathematical tool that helps determine how far the values of data are spread above and below the mean. The skewness in FAFG is negative, but the other variables are moderately and positively skewed. The implication is that the negative skewness in FAFG might give room for extremely negative occurrence of economic situations. The distribution in 


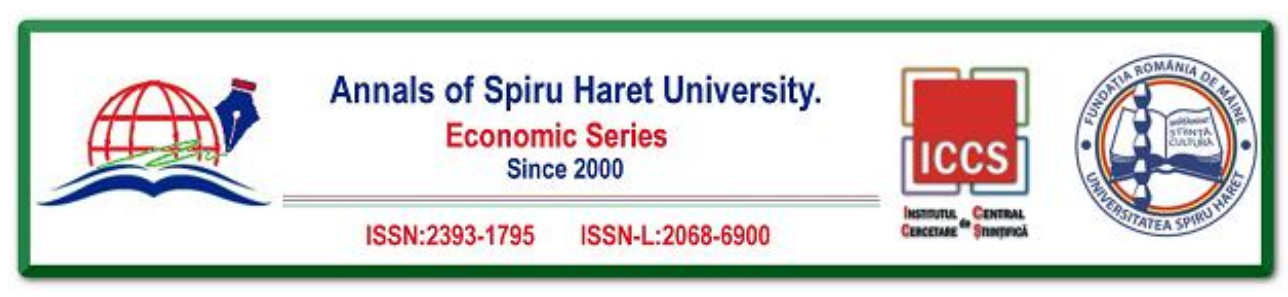

\section{Issue 4/2018}

NDSD is the only one that is greater than 3 , which suggests more values than the normal distribution and could lead to extreme positive or negative economic outcomes.

Table 1. FAA and PCI Descriptive Statistics

\begin{tabular}{|l|c|c|c|c|c|}
\hline & $\begin{array}{c}\text { PCI AT 1 } \\
\text { DIFFERENCE }\end{array}$ & $\begin{array}{c}\text { LOGFAFG AT } \\
1^{\text {ST }} \\
\text { DIFFERENCE }\end{array}$ & $\begin{array}{c}\text { FASG AT 2 } \\
\text { DIFFERENCE }\end{array}$ & $\begin{array}{c}\text { FALG AT } \\
\text { LEVEL }\end{array}$ & $\begin{array}{c}\text { NDSD AT 2 } \\
\text { DIFFERENCE }\end{array}$ \\
\hline Mean & 250951.6 & 5.925880 & 563.0756 & 287.6953 & 344.8844 \\
\hline Median & 213241.5 & 5.953927 & 84.86500 & 37.23500 & 22.50000 \\
\hline Maximum & 385227.6 & 8.928023 & 2122.920 & 1125.080 & 1638.000 \\
\hline Minimum & 173011.9 & 2.282382 & 2.720000 & 0.000000 & 0.000000 \\
\hline Std. Dev. & 71878.01 & 2.390014 & 707.0765 & 372.0361 & 501.4575 \\
\hline Skewness & 0.728329 & -0.219547 & 0.956978 & 0.968926 & 1.453453 \\
\hline Kurtosis & 1.929100 & 1.525501 & 2.503586 & 2.523030 & 3.984054 \\
\hline & & & & & \\
\hline Jarque-Bera & 4.903022 & 3.550428 & 5.864482 & 5.974160 & 14.12770 \\
\hline Probability & 0.086163 & 0.169447 & 0.053278 & 0.050435 & 0.000855 \\
\hline & & & & & \\
\hline Sum & 9034257. & 213.3317 & 20270.72 & 10357.03 & 12415.84 \\
\hline Sum Sq. Dev. & $1.81 \mathrm{E}+11$ & 199.9258 & 17498500 & 4844380. & 8801086. \\
\hline & & & & 36 & 36 \\
\hline Observations & 36 & 36 & & & \\
\hline
\end{tabular}

Source: Researcher's Computation, 2018.

From table 2 above, the correlation (R) of 96.14\% (Square root of R-squared) is an indication that PCI and the predictor variables have a strong positive relationship. R-squared of $92.43 \%$ signifies the magnitude to which the predictor variables could explain the changes in the PCI. To that effect, it is notable that up to $7.57 \%$ could not be accounted for by the factors captured in the model. The Durbin-Watson of 1.44 is within the acceptable limit based on the rule of thumb. 


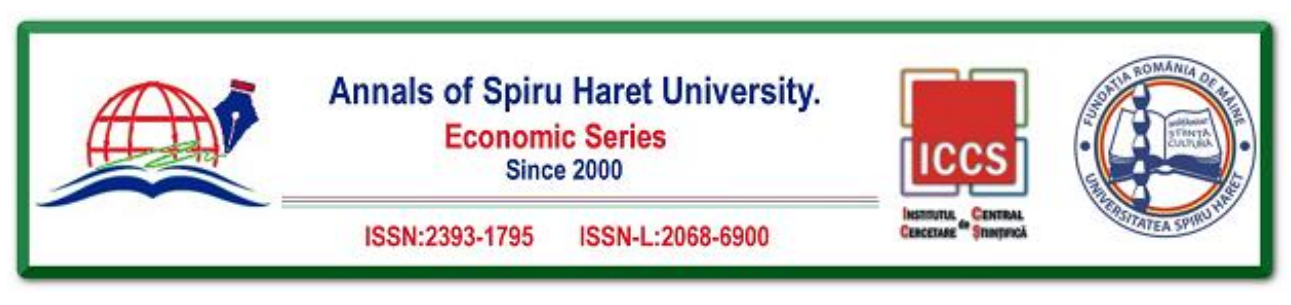

Issue $4 / 2018$

The regression result on table 1 reveals that F-statistics is 94.63019 with the pvalue of $0.0000<0.05$ and is statistically significant and robust. This implies that the revenue allocation to the three tiers of the government and the derivation allowance collectively and jointly impact on PCI positively and significantly.

Table 2. FAA and PCI Regression Result

\begin{tabular}{|c|c|c|c|c|}
\hline \multicolumn{4}{|c|}{ Dependent Variable: PCIAT1STDIFFRNCE } & \\
\hline \multicolumn{3}{|l|}{ Method: Least Squares } & & \\
\hline \multicolumn{4}{|l|}{ Date: 06/20/18 Time: 13:07 } & \\
\hline \multicolumn{3}{|l|}{ Sample: 19812016} & & \\
\hline \multicolumn{3}{|l|}{ Included observations: 36} & & \\
\hline & & & & \\
\hline Variable & Coefficient & Std. Error & t-Statistic & Prob. \\
\hline & & & & \\
\hline LOGFAFGAT1STDIFFERENCE & -5563.493 & 2767.586 & -2.010233 & 0.0532 \\
\hline FASGAT2NDDIFFERENCE & -108.2019 & 50.91706 & -2.125062 & 0.0417 \\
\hline FALGATLEVEL & 478.5012 & 100.8886 & 4.742867 & 0.0000 \\
\hline NDSDAT2NDDIFFERENCE & -48.96020 & 20.85055 & -2.348149 & 0.0254 \\
\hline $\mathrm{C}$ & 224069.1 & 12736.78 & 17.59228 & 0.0000 \\
\hline R-squared & 0.924302 & \multicolumn{2}{|c|}{ Mean dependent var } & 250951.6 \\
\hline Adjusted R-squared & 0.914534 & \multicolumn{2}{|c|}{ S.D. dependent var } & 71878.01 \\
\hline S.E. of regression & 21013.20 & \multicolumn{2}{|c|}{ Akaike info criterion } & 22.87194 \\
\hline Sum squared resid & $1.37 \mathrm{E}+10$ & \multicolumn{2}{|c|}{ Schwarz criterion } & 23.09187 \\
\hline Log likelihood & -406.6948 & \multicolumn{2}{|c|}{ Hannan-Quinn criter. } & 22.94870 \\
\hline F-statistic & 94.63019 & \multicolumn{2}{|c|}{ Durbin-Watson stat } & 1.442820 \\
\hline Prob (F-statistic) & 0.000000 & & & \\
\hline & & & & \\
\hline
\end{tabular}

Source: Researcher's Computation, 2018. 


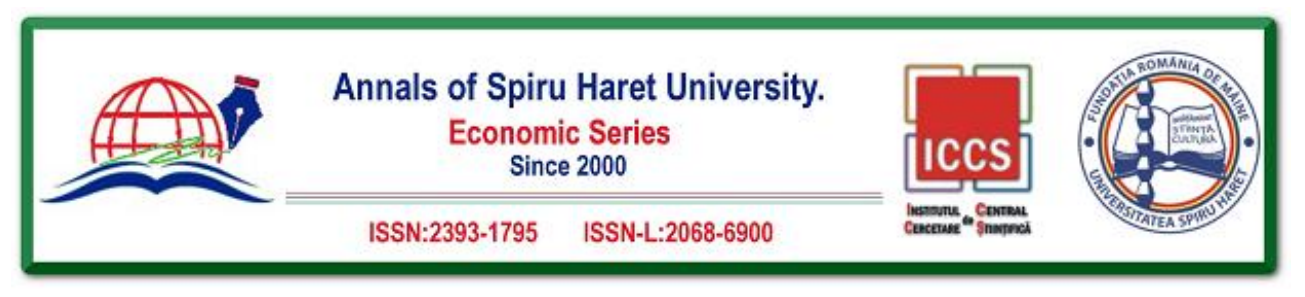

\section{Issue 4/2018}

\section{Test of Hypothesis}

The earlier study hypothesized that revenue allocation to the three tiers of the government and the derivation allowance to the Niger Delta States do not have significant impact on PCI. The t-statistics for all the independent variables provide evidence that the FASG and NDSD have significant negative impact on PCI, while FAFG has insignificant negative impact on PCI. Therefore, the $\mathrm{Ho}_{1}, \mathrm{Ho}_{2}$, and $\mathrm{Ho}_{4}$ have been accepted and the alternative rejected. On the contrast, the result shows that FALG has a robust significant positive impact on PCI. Thus, $\mathrm{Ho}_{3}$ has been rejected and the alternative which stated otherwise accepted. This result is in agreement with the findings of Dagwom (2013), Ojide \& Ogbodo (2015), Usman (2011), but conflicts with Ohiomu \& Oluyemi (2017) who found that FALG had negative influence on the economy.

\section{Conclusion and Recommendation}

From the regression result of this study, the revenue allocation to federal and state reflected insignificant and significant negative impact on per capita income respectively. The derivation allowance to the Niger Delta States equally has significant negative impact on per capita income. Revenue allocation to the local government showed significant positive impact confirming the fact that government at the local levels are better positioned to meet the needs of the people since it is closer to the people than the federal government. Therefore, the study recommends more revenue allocation to the local government councils since they are closer to the people and are in the best position to boost economic through attending the infrastructural needs that are glaring to them. The study is also suggesting more stringent measures in dealing with corrupt practices in the government system, which will guarantee efficient and effective use of resources to achieve the economic goals.

\section{References}

1. Arowolo, D. (2011). "Fiscal Federalism in Nigeria: Theory and Dimensions." Afro Asian Journal of Social Sciences, 2(22), 1-21.

2. ATSWA (2009). Public Sector Accounting. Accounting Technicians Scheme (West Africa). Second Edition. ABWA Publishers.

3. Bashir, K. A. "The Mechanisms of Revenue Allocation: Understanding the Need for Effective Data Collection and Management.” Workshop Paper, 2008.

4. Business Dictionary (2017). "What Is Per Capita Income?” www.businessdictionary.com/. Retrieved: January 4, 2018. 


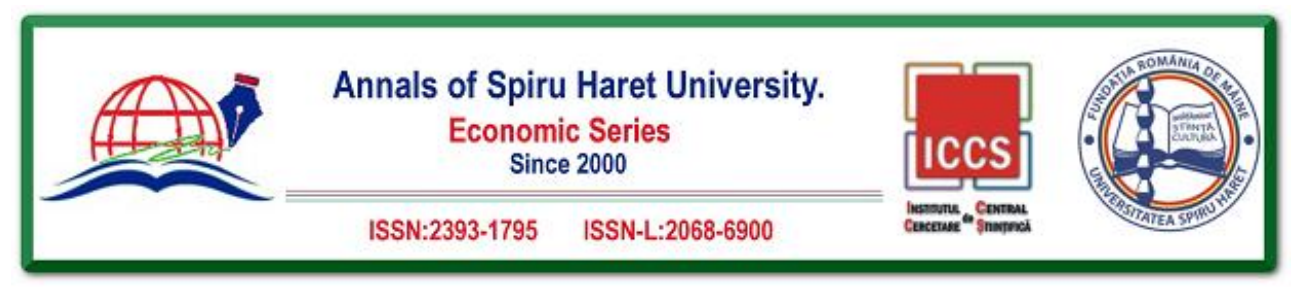

Issue $4 / 2018$

5. Central Bank of Nigeria. CBN Statistical Bulletin. Abuja, Nigeria, 2016.

6. Dagwom, Y. D. (2013). "Revenue Allocation and Economic Development in Nigeria: An Empirical Study.” SAGE Open. July-September, pp. 1-7.

7. Domar, E. Essays in the Theory of Economic Growth. New York, NY: Oxford University Press, 1957.

8. Ekpo, A. H. Intergovernmental fiscal relations: The Nigerian experience. Paper presented at the $10^{\text {th }}$ anniversary of the Financial and Fiscal Commission of South Africa, Cape Town International Convention Centre, Cape Town, South Africa, August 10-12, 2004.

9. Faridi, M. Z. (2011). “Contribution of Fiscal Decentralization to Economic Growth: Evidence from Pakistan.” Pakistan Journal of Social Sciences (PJSS), 31(1), 1-13.

10. Farlex, Inc. (2018). Per capita income. TheFreeDictionary.com. Retrieved October 19 2018 from https://acronyms.thefreedictionary.com/per+capita+income

11. Focus Economics (2017). What Is GDP Per Capita? https://www.focus.economics.com/. Retrieved: January 2, 2018.

12. Harrod, R. F. (1939). “An Essay in Dynamic Theory.” The Economic Journal, 49(193), 14-33. Doi: $10.2307 / 2225181$. JSTOR.

13. Ihe, N. J., \& Umeaka, E. C. Public Sector Accounting and Finance (The Nigerian Perspective). Peace Publishers Limited, Owerri, Nigeria, 2006.

14. Ikeji, C. C. (2011). "Politics of Revenue Allocation in Nigeria: A Reconsideration of Some Contending Issues.” Sacha Journal of Policy and Strategic Studies, 1(1), 121-136.

15. Investopedia (2017). Real Gross Domestic Product (GDP). Investopedia, LLC. Retrieved on: December, 20 from: https://www.investopedia.com/.

16. Micaiah, W. (2015). Nigerian Government Revenue Allocation. Statisence. https://www.slideshare.net/statisense/nigerian-government-revenue-allocation. Retrieved July 31, 2017.

17. National Revenue Mobilization, Allocation and Fiscal Commission (1992). Revenue Allocation. Notes on the Role and Activities of the NRMAFC, presented at the National seminar on Revenue mobilization for states and local governments, Enugu April 21-23.

18. Nnamocha, P. N. Public Finance for a Developing Economy: The Nigerian Application. Bon Publisher Owerri, Imo State, Nigeria, 2002.

19. Odigwe, D. A., \& Aibieyi, S. (2015). "Fiscal Federalism and Development in Nigeria." Public Policy and Administration Research, 5(7), 36-44.

20. Ohiomu, S., \& Oluyemi, S. A. (2017). "Fiscal Federalism and Economic Growth Nexus: Empirical Evidence from Nigeria.” International Journal of Economics, Commerce and Management United Kingdom, 5(2), 131-146.

21. Ojide, M. G., \& Ogbodo, J. C. (2015). "Federation Account Allocation in Nigeria: Implication for Growth. “ Journal of Poverty, Investment and Development, 7, 8-11.

22. Olaoye, F. O., \& Adedeji, Q. A. (2017). "Performance Benchmarking of Selected Southwest States Government.” Advances in Social Sciences Research Journal, 4(24), 88-94. 


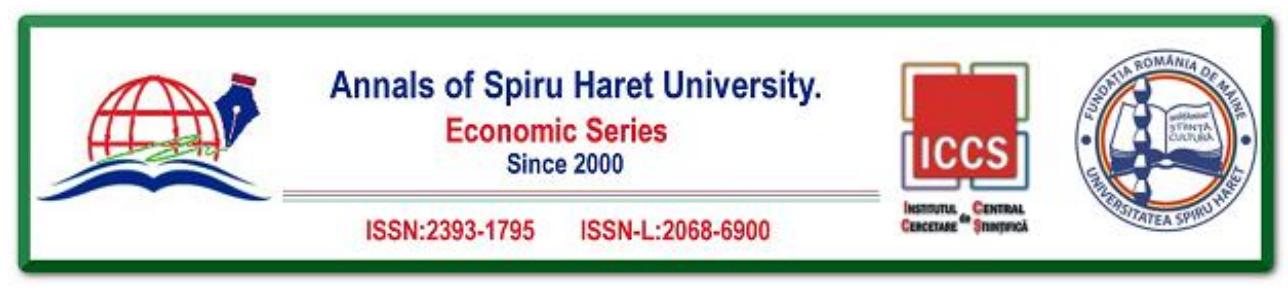

\section{Issue 4/2018}

23. Onu, O. "Federal - State Fiscal Relation.” In Eliagwu, I. T. et al, (Eds) Federalism and National Building in Nigeria. Abuja: National Council of Inter-governmental Relations, 1994.

24. Orluwene, O. B. The Politics of Revenue Allocation in Nigeria since Independence: An Overview. Selected Works, 2008, http://works.bepress.com/ozyb-orluwene/4/.

25. Roma, P. M. (1994). “The origins of Endogenous Growth.” The Journal of Economic Perspectives, 8(1), 3-22.

26. Solow, R. M. (1956). "A Contribution to the Theory of Economic Growth.” Quarterly Journal of Economics, 70(1), 65-94.

27. Swan, T. W. (1956). "Economic Growth and Capital Accumulation.” Economic Record, 32:334-61. Doi:10.1111/j.1475-4932.1956.tb00434.x.

28. Usman, O. A. (2011). "Revenue Allocation Formula and Its Impact on Economic Growth Process in Nigeria." Journal of Economics and Sustainable development, 2(3), 29-37.

29. World Bank (2017). Nigeria: Gross Domestic Product per Capita (Constant LCU). Available at: https://data.worldbank.org/indicator/NY.GDP.PCAP.KN?view=chart. 